\title{
BERTRAM W. CARTWRIGHT (1890-1967)
}

by C. Stuart Houston, 863 University Drive, Saskatoon

B. W. Cartwright, Chief Naturalist for Ducks Unlimited from its founding in 1937 until his retirement in 1960 , died of a heart attack in Richmond, B.C. on June 16, 1967.

Born in Malvern, England in 1890, he became interested in birds at an early age, finding the nest of the rare Ring Ouzel when he was only 12. He was a junior member of the Bolton Field Naturalists' Club until his family emigrated to Winnipeg in 1911. There with A. G. Lawrence and H. M. Speechly he helped form the Manitoba Natural History Society in 1921. He worked for the CNR, Eaton's and a stationery firm until 1937 when Ducks Unlimited (Canada) was formed and he was asked to join their full-time staff as chief naturalist.

During his frequent trips across the prairies he became acquainted with many prairie birdwatchers and particularly those interested farmers and sportsmen who served without pay as D.U. "Kee-men." He organized extensive waterfowl banding activities and this led to the publication of "Waterfowl Banding 1939-1950" in 1952 and a revised "Waterfowl Band" ing 1939-1954" in 1956. The cover photograph of the first edition showed Mrs. Isabel M. Priestly releasing a banded Mallard.

Most of his scientific papers naturally dealt with waterfowl on the prairies, though he co-authored a monograph on Baird's Sparrow and edited C. G. Harrold's important notes on the Birds of Lake Johnston (Old Wives Lake) after Harrold's death. One thoughtful paper, contrary to the D.U. predator campaigns, speculated on the possible benefits of crow predation on upland game: a staggered nesting season, caused by renesting after initial predation, would allow some of the young grouse to avoid dangerous cold wet periods. He was co-author of the beautiful volume of waterfowl paintings by Angus $H$.
Shortt published in 1948 and entitled "Know Your Ducks and Geese." In 1928 he originated "Wild Wings", a weekly nature column in the Winnipeg Tribune, which he wrote for 17 years.

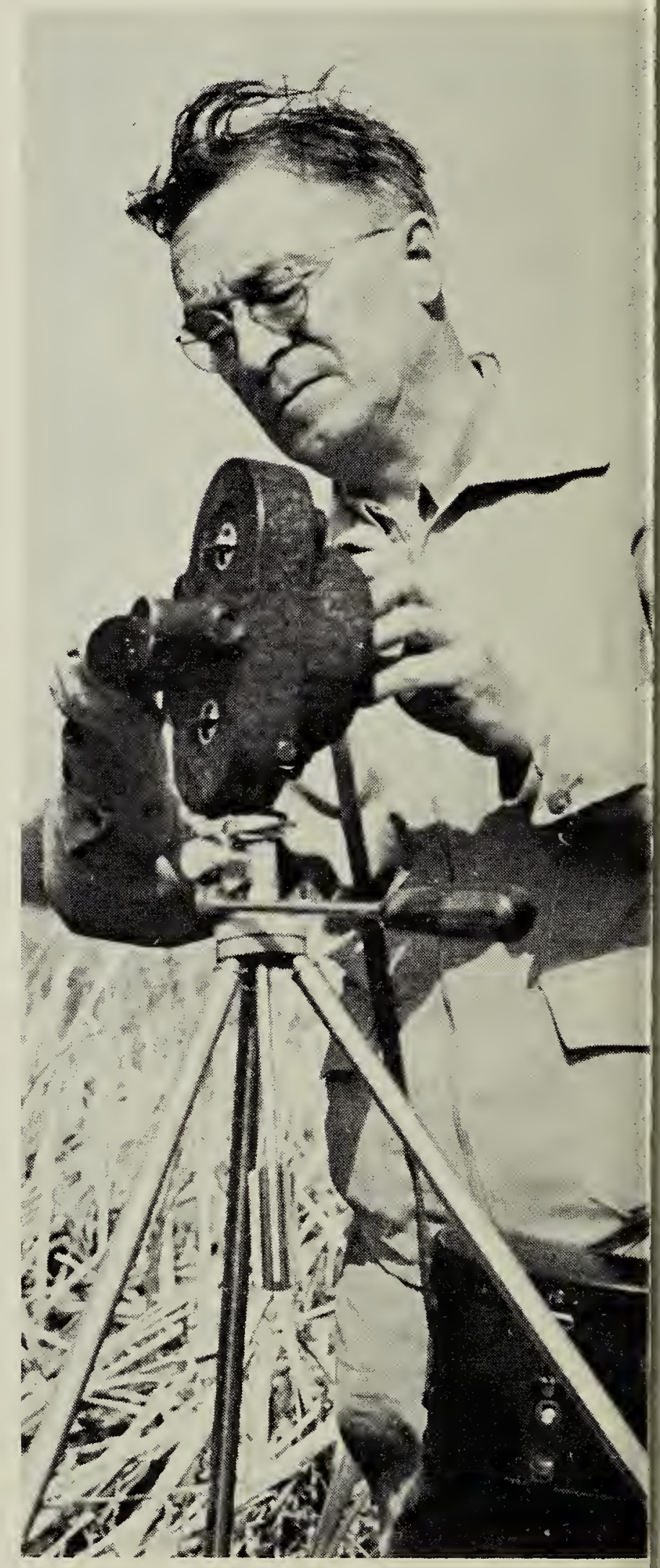

Photo by Ducks Unlimited (Canada: 